\title{
Thermal treatments affected to quality attributes of Solanum procumbens Lour.
}

\author{
Nguyen Phuoc Minh \\ Institute of Applied Technology, Thu Dau Mot University, Binh Duong Province, Vietnam \\ *Email: nguyenphuocminh@tdmu.edu.vn
}

OPEN ACCESS

\section{ARTICLE HISTORY}

Received: 06 July 2021

Accepted: 17 September 2021

Available online

Version 1.0 (Early Access): 15 October 2021

Version 1.1 (Early Access): 27 October 2021

Version 2.0: 01 January 2022

\section{Check for updates}

\section{Additional information}

Peer review: Publisher thanks Sectional Editor and the other anonymous reviewers for their contribution to the peer review of this work.

Reprints \& permissions information is available at https://horizonepublishing.com/ journals/index.php/PST/open_access_policy

Publisher's Note: Horizon e-Publishing Group remains neutral with regard to jurisdictional claims in published maps and institutional affiliations.

Indexing: Plant Science Today, published by Horizon e-Publishing Group, is covered by Scopus, Web of Science, BIOSIS Previews, Clarivate Analytics, etc. See https:// horizonepublishing.com/journals/index.php/ PST/indexing_abstracting

Copyright: ( $)$ The Author(s). This is an openaccess article distributed under the terms of the Creative Commons Attribution License, which permits unrestricted use, distribution and reproduction in any medium, provided the original author and source are credited (https://creativecommons.org/licenses/ by/4.0/)

\section{CITE THIS ARTICLE}

Minh NP. Thermal treatments affected to quality attributes of Solanum procumbens Lour. Plant Science Today. 2022;9(1):150-156. https://doi.org/10.14719/pst.1370

\begin{abstract}
Solanum procumbens Lour. has been distributed in many places of Vietnam and tropical regions. Its extract includes numerous therapeutic properties in pharmacopeia. This research evaluates the possibility of dried herbal tea production from this valuable phytochemical source. Different variables of vapor steaming, convective drying, and roasting are verified to monitor the degradation of total phenolic content, total flavonoid content, diphenylpicrylhydrazyl (DPPH) free radical scavenging, ferric reducing antioxidant power (FRAP) and overall acceptance in S. procumbens. Results show that $S$. procumbens should be blanched by steaming within $45 \mathrm{~s}$ as primary treatment, dehydrated at $45 / 7.0^{\circ} \mathrm{C} / \mathrm{hrs}$, roasted at $150 / 20^{\circ} \mathrm{C} / \mathrm{min}$ to preserve the most antioxidant constituents with total phenolic content, total flavonoid content, half inhibitory concentration (IC50) of DPPH, FRAP as well as the highest organoleptic value. High retention of total phenolic content, total flavonoid content, antioxidant power as well as high sensory score of the dried S. procumbens herbal tea plays an important decision in consumer preference and acceptance. All these processing steps can be performed in simple handling with universal available equipments like steaming oven, convective drier and roasting oven. Findings in this study will be useful data for house-hold scale production.
\end{abstract}

\section{Keywords}

antioxidant, drying, herbal tea, roasting, steaming, Solanum procumbens

\section{Introduction}

Solanum procumbens Lour. Is a well-known in folk medicine against different chronic ailments due to its diversified phytochemical constituents like phenolics, flavonoids, glycoalkaloids and coumarins (1). Different biological properties such as antimicrobial, anti-inflammatory, cytotoxic, antifungal, antiviral and antioxidant potential has been reported on Solanum sp. (2). It has been especially demonstrated to be effective in treating arthritis, cancer and hepatitis (3). Numerous chemical substances have been discovered in this valuable plant including indole-3-carbaldehyde, ziganein, vanillic acid, benzoic acid, 4-hydroxybenzaldehyde and salicylic acid (4). The most important compound has been investigated namely solacanin with excellent $\alpha$ -glucosidase inhibitory capacity (5). Apart from natural collection, it has also been propagated via seedling production to satisfy planting and processing demands.

Pretreatment before dehydration is very necessary to high-quality dehydrated plants, limited drying duration and minimal energy requirement 
(6). Steaming has shown numerous advantages for herbal dehydration. The most advantage of steaming is limitation of discoloration. The steamed parsley gives 30\% more quickly dehydrating speed and $72 \%$ energy consuming reduction. The dehydrated parsley has better lutein content and excellent color sustain (7). Thermal pre-treatment induces higher chlorophyll sustain and better rehydration power of the dehydrated coriander leaves compared to control ones (8). However, steaming induces a great reduction of antioxidant potentials in herbal plants (9). Convective drying is one of the most basic, simple and efficient methods in food processing and preservation. It has been commonly utilized in non-tropical regions where sunlight is not enough. Dehydrating temperature, dehydrating duration and air speed have been totally controlled (10). Dehydration of herb by convective drying is mostly affected by different drying variables like air speed, temperature and moisture gradient (11). To achieve the best processing efficiency and capacity, they should be optimal with high drying load in short processing time with minor impact to the thermal sensitive constituents in medicinal plants. It is very important to preserve value-added substances and sensory quality attributes in raw medicinal material during drying (12). There has been a positive correlation between air drying temperature and volatile removal, especially with lower boiling point (13). Under thermal treatment, moisture is removed out of fresh materials inducing to solid-dehydrated products (14). There have been two types of moisture including unbounded and bound water. Unbounded water is easily escaped from food matrix by diffusion, migration and evaporation (15). Moisture removal out of fresh materials will facilitate for inhibition of microbial growth and proliferation; enzyme activity decreased; overall acceptance either increased or decreased leading to extension of product stability (16). High temperature of convective dehydration results to major decomposition of herbal flavors and pigments (17). High shrinkage on the finished product is one of the main restrictions of convective drying (10). Dehydration will be a smart strategy to decrease weight and volume thus facilitating for packaging, preservation and distribution. Due to low moisture content, the dried plant has better resistance to microbial invasion and enzymatic reaction with an extended shelf life (18). Low energy consumption during convective drying is also very important to reduce production cost towards sustainable production with minor environmental impact.

Green tea has been obtained from drying and roasting meanwhile black tea has been normally achieved from fermentation (19). Roasting has been also an important step to accomplish the dried herbal tea production. Roasting has been commonly applied in herbal tea dehydration to avoid any excess pharmacological reactions, mild side effects, alter functional characteristics and cover bad behaviors (20). Roasting greatly improves the specific flavors of herbal tea (21). Maillard reaction products have been formed via roasting (22). Roasting strongly contributes to consumer's acceptance apart from physicochemical and antioxidant attributes of herbal tea (23). Roasting creates a significant impact to bioactive components like phenolics, flavonoids, vitamins. Roasting has been demonstrated causing partially loss of chlorogenic acids (24). The bioactive degradation by thermal roasting is totally relied on temperature, time and heating ways (25). Herbal tea production can be processed from various thermal treatments in different ways from pilot model by simple techniques to huge industrial scale by innovative technologies. Modern treatment methods like steam explosion, shockwave have drawn a great attention. An investigation enable to produce underwater high-voltage discharges (3.5 kV) combined with aqueous plasma expansion has been conducted. The degree of phytomass demolition induced by infusion of the pressure shockwaves (50-60 MPa) accompanied by this extension has been evaluated applying gas adsorption method. The kinetics of the outer layer region and the micropore dimension on different pretreatment periods of corn silage and sunflower seeds has been verified with reliable analytical procedures. The multiple accelerates on the reaction layer have scaled up to a $15 \%$ rising in amassed methane emission, which has itself evolved in the overall increment of the anaerobic fermentation. Exploitation of the sunflower seeds permits up to $45 \%$ higher oil volume applying the similar active pressure (26). Innovation of new methods taking by-product without any supplemental power or minimal catalysts is a beginning basic for inducing sustainable. The intricate application of greenhouse balances has been examined on an industrial scale. Minimal power manufactured by the process has been utilized to perform the technology, due to diversified thermal recirculation and abundant methane volume. Propagation of labile carbon in relation to available nitrogen, methane volume and the production of preventers have been examined thoroughly. These findings have eliminated different negative behaviors about the proportion of carbon to nitrogen and emphasize the function of the availability of carbon in phyto-mass usage (27).

The antioxidant activity participates in retardation of chain initiation, degradation of peroxides and limitation of ongoing hydrogen abstraction, free radical scavenging, reducing capacity and capturing of transition-metal ion catalysts. DPPH is the free radical and collected an electron or hydrogen radical to form a sustainable diamagnetic molecule. FRAP serves reducing power as a key indicator of its antioxidant activity. In order to utilize raw Solanum procumbens as a valuable material for herbal tea production at house-hold scale, purpose of our study focuses on the impact of different thermal treatments such as vapor steaming, convective drying and roasting to antioxidant and organoleptic properties of herbal tea from Solanum procumbens. Adaptable experiments with universal available equipments like steaming oven, convective drier and roasting oven were applicable in this research. Therefore, it is absolutely feasible to implement at small and medium scale production; there is no need to rely on hi-tech equipments or high capital investment that will be a promising potential for start-up. This research finding will better preserve phytochemical constituents in Solanum procumbens. 


\section{Materials and Methods}

Solanum procumbens has been planted and collected since 2019 in Binh Phuoc province, Vietnam. Before planting, put the seeds in water for about $40{ }^{\circ} \mathrm{C}$ and soak for 15 $\mathrm{min}$, the purpose of soaking in warm water is to quickly germinate. The seeds that float to the surface of the water are removed because these are flat seeds. The trees are planted in the rainy season. The density of row size is $50 \times$ $50 \mathrm{~cm}$, plant spacing is $50 \times 50 \mathrm{~cm}$. When planting, remove the potting bag to reach the tree in the middle of the hole, straighten the tree, fill it with soil and compact the soil at the base, after planting, water the plants a little to avoid water withdrawal. Water is necessary to provide enough water for the tree, especially in the dry season, when the fruit is growing and when the fruit is ready to ripen. The trees with good care after only 4 months can be harvested by collecting the stem, roots. It is free from insect, disease and pesticide. It was washed under clean water to remove foreign matters. Chemical reagents such as FolinCiocalteu phenol, DPPH (2, 2-Diphenyl picrylhydrazyl) reagent, FRAP reagent, gallic acid, catechin reagent, sodium carbonate, methanol $\mathrm{FeCl}_{3} \cdot 3 \mathrm{H}_{2} \mathrm{O}$ are all analytical grade purchased from Fluka (Switzerland) and Sigma Aldrich (USA). Lab apparatus and equipments include test tube, cylinder, beaker, Erlenmeyer flask, vortex mixer, steaming oven, convective drier, roasting oven, UV-Vis spectrophotometer.

\section{Researching method}

Solanum procumbens is steam-blanched at $110{ }^{\circ} \mathrm{C}$ in different duration $(15,30,45,60$ and $75 \mathrm{~s})$, dehydrated by convective drying $\left(35 / 8.0,40 / 7.5,45 / 7.0,50 / 6.5\right.$ and $55 / 6.0^{\circ} \mathrm{C} /$ hrs), roasting (140/30,145/25, 150/20, 155/15 and 160/10 ${ }^{\circ} \mathrm{C} / \mathrm{min}$ ). In each experiment, samples have been taken to determine total phenolic content, total flavonoid content, DPPH free radical scavenging, FRAP ferric reducing antioxidant and overall acceptance (28).

Total phenolic content or TPC (mg GAE/100 g) is estimated by Folin-Ciocalteu reagent assay (29). Aluminum chloride colorimetric method is applied for quantification of total flavonoid content or TFC (mg QE/100 g) (30). DPPH free radical scavenging $\left(\mathrm{IC}_{50}, \mu \mathrm{g} / \mathrm{ml}\right)$ is estimated using UV-VIS spectrophotometric method at wavelength $517 \mathrm{~nm}$ (31). FRAP (mg ascorbic acid equivalents/ $\mathrm{ml}$ ) ferric reducing antioxidant has been defined as power inreducing of $\mathrm{Fe}^{+3}$ to $\mathrm{Fe}^{+2}$ by an antioxidant using the method described by Benzie and Strain (32). Overall acceptance is determined by a group of specialists using 9-point Hedonic scale.

\section{Statistical analysis}

The experiments are run in triplicate with different groups of samples. The data are presented as mean \pm standard deviation. Statistical analysis is performed by the Statgraphics Centurion version XVI.

\section{Results and Discussion}

The effect of steaming at $110{ }^{\circ} \mathrm{C}$ in different times (s) to antioxidant and organoleptic properties of raw and steamed Solanum procumbens is clearly presented in Table 1. It's obviously noticed that the raw S. procumbens contains a great amount of total phenolic content $(243.18 \pm 0.24 \mathrm{mg} \mathrm{GAE} / 100 \mathrm{~g})$ and total flavonoid content (169.73 $\pm 0.09 \mathrm{mg} \mathrm{QE} / 100 \mathrm{~g})$ contributing to an excellent antioxidant power with $\mathrm{IC}_{50}$ of DPPH $(11.52 \pm 0.04 \mu \mathrm{g} / \mathrm{ml})$, $\operatorname{FRAP}(0.97 \pm 0.03 \mathrm{mg} \mathrm{AAE} / \mathrm{ml})$. The steaming at $110^{\circ} \mathrm{C}$ for 15 -45s causes a slight decomposition of total phenolic content (194.53 \pm 0.15 down to $141.12 \pm 0.23 \mathrm{mg} \mathrm{GAE} / 100 \mathrm{~g}$ ), total flavonoid content $(112.08 \pm 0.10$ down to $79.42 \pm 0.06$ $\mathrm{mg} \mathrm{QE} / 100 \mathrm{~g}), \mathrm{IC}_{50}$ of DPPH (17.84 \pm 0.03 up to $19.04 \pm 0.03$ $\mu \mathrm{g} / \mathrm{ml})$, FRAP $(0.73 \pm 0.01$ down to $0.51 \pm 0.04 \mathrm{mg} \mathrm{AAE} / \mathrm{ml})$. However, extension of steaming time from $60-75$ s causes a significant reduction of total phenolic content $(80.09 \pm 0.12$ down to $47.84 \pm 0.09 \mathrm{mg} \mathrm{GAE} / 100 \mathrm{~g}$ ), total flavonoid content (31.03 \pm 0.13 down to $12.08 \pm 0.05 \mathrm{mg} \mathrm{QE} / 100 \mathrm{~g}$ ), IC 50 of DPPH $(25.19 \pm 0.02$ up to $33.79 \pm 0.00 \mu \mathrm{g} / \mathrm{ml})$, FRAP $(0.23 \pm 0.01$ down to $0.09 \pm 0.03 \mathrm{mg} \mathrm{AAE} / \mathrm{ml}$ ). The highest overall acceptance $(7.07 \pm 0.02)$ is noticed at sample steamed at $110^{\circ} \mathrm{C}$ for $45 \mathrm{~s}$ while the lowest sensory score $(4.32 \pm 0.02)$ is recorded at sample steamed at $110^{\circ} \mathrm{C}$ for $75 \mathrm{~s}$. Therefore steaming at $110{ }^{\circ} \mathrm{C}$ for $45 \mathrm{~s}$ is selected for further experiments. Blanching/steaming has been recommended as pre-treatment for pepper before convective drying to control enzymatic browning and reduce drying duration. Dried pepper will obtain better pungency, flavor and color by this steaming in advance of the official convective dehydration (33). Asparagus blanched in hot water before convective drying results tobetter reconstitution and fine structure (34). The steamed dehydrated basil leaves reveal higher color retention (35). Roselle calyx steamed at $115^{\circ} \mathrm{C}$ for 30 seconds preserves the highest total phenolic and flavonoid content (20). Polyscias fruticosa steamed in vapor for 30 seconds results to better retention of total phenolic, total flavonoid, DPPHradical-scavenging ability and FRAP ferric reducing antioxidant power (36).

The effect of convective drying at different conditions (35/8.0, 40/7.5, 45/7.0, 50/6.5 and 55/6.0, $\left.{ }^{\circ} \mathrm{C} / \mathrm{hrs}\right)$ to antioxidant and organoleptic properties of steamed and dried S. procumbens has been thoroughly elaborated in Table 2. It's clearly realized that the steamed S. procumbens contains a remarkable amount of total phenolic content (141.12 $\pm 0.23 \mathrm{mg} \mathrm{GAE} / 100 \mathrm{~g})$ and total flavonoid content $(79.42 \pm 0.06 \mathrm{mg} Q E / 100 \mathrm{~g})$ contributing to a high antioxidant power with IC 50 of DPPH $(19.04 \pm 0.03 \mu \mathrm{g} / \mathrm{ml})$, FRAP $(0.51 \pm 0.04 \mathrm{mg} A A E / \mathrm{ml})$ as well as overall acceptance (7.07 \pm 0.02$)$. The convective drying at $45 / 7.0\left({ }^{\circ} \mathrm{C} / \mathrm{hrs}\right)$ causes a slight degradation of total phenolic content $(132.41 \pm 0.06$ $\mathrm{mg} \mathrm{GAE} / 100 \mathrm{~g})$, total flavonoid content $(71.24 \pm 0.02 \mathrm{mg}$ QE/100 g), IC $C_{50}$ of DPPH $(19.67 \pm 0.01 \mu \mathrm{g} / \mathrm{ml})$, FRAP $(0.46 \pm 0.01 \mathrm{mg} \mathrm{AAE} / \mathrm{ml})$ and overall acceptance $(8.12 \pm 0.03)$. Therefore convective drying at $45 / 7.0\left({ }^{\circ} \mathrm{C} / \mathrm{hrs}\right)$ is selected for further experiments. In another report, inhibitory capacity of $S$. procumbens has been noticed at $\mathrm{IC}_{50}$ values of $221.5 \mu \mathrm{M}$ (5). The long-standing duration of hot air contact the more color depression is (14). Temperature at $50{ }^{\circ} \mathrm{C}$ has been recommended for convective drying of okra to maintain nutritional proximate, preserve bioactive ingredients and stabilize organoleptic attributes (37). Convec- 
Table 1. Effect of steaming at $110{ }^{\circ} \mathrm{C}$ in different times (s) to antioxidant and organoleptic properties of raw and steamed Solanum procumbens.

\begin{tabular}{|c|c|c|c|c|c|c|}
\hline Steaming time (s) & Raw & 15 & 30 & 45 & 60 & 75 \\
\hline $\begin{array}{l}\text { TPC } \\
(\mathrm{mg} \mathrm{GAE} / 100 \mathrm{~g})\end{array}$ & $243.18 \pm 0.24^{\mathrm{a}}$ & $194.53 \pm 0.15^{b}$ & $167.41 \pm 0.18^{\mathrm{bc}}$ & $141.12 \pm 0.23^{c}$ & $80.09 \pm 0.12^{d}$ & $47.84 \pm 0.09 \mathrm{e}$ \\
\hline $\begin{array}{l}\text { TFC } \\
(\mathrm{mg} \mathrm{QE} / 100 \mathrm{~g})\end{array}$ & $169.73 \pm 0.09^{a}$ & $112.08 \pm 0.10^{\mathrm{b}}$ & $93.59 \pm 0.07^{\mathrm{bc}}$ & $79.42 \pm 0.06^{c}$ & $31.03 \pm 0.13^{d}$ & $12.08 \pm 0.05^{\mathrm{e}}$ \\
\hline $\begin{array}{l}\text { DPPH } \\
\left(I C_{50}, \mu \mathrm{g} / \mathrm{ml}\right)\end{array}$ & $11.52 \pm 0.04^{\mathrm{e}}$ & $17.84 \pm 0.03^{d}$ & $18.65 \pm 0.01^{c d}$ & $19.04 \pm 0.03^{c}$ & $25.19 \pm 0.02^{\mathrm{b}}$ & $33.79 \pm 0.00^{\mathrm{a}}$ \\
\hline $\begin{array}{l}\text { FRAP } \\
\text { (mg AAE/ml) }\end{array}$ & $0.97 \pm 0.03^{a}$ & $0.73 \pm 0.01^{b}$ & $0.65 \pm 0.02^{\mathrm{bc}}$ & $0.51 \pm 0.04^{c}$ & $0.23 \pm 0.01^{\mathrm{d}}$ & $0.09 \pm 0.03^{e}$ \\
\hline $\begin{array}{l}\text { Overall acceptance } \\
\text { (score) }\end{array}$ & $6.51 \pm 0.01^{\mathrm{b}}$ & $5.30 \pm 0.00^{\mathrm{d}}$ & $5.63 \pm 0.03^{c}$ & $7.07 \pm 0.02^{\mathrm{a}}$ & $5.49 \pm 0.01^{c d}$ & $4.32 \pm 0.02^{\mathrm{e}}$ \\
\hline
\end{tabular}

tive dehydration with a quick drying speed at the initial of pomegranate (48), 50-90 ${ }^{\circ} \mathrm{C}$ forblackcurrant $(49), 50-70{ }^{\circ} \mathrm{C}$ the dehydration may induce to rigid structure and inferior for jujube $(41), 40-60^{\circ} \mathrm{C}$ for cacao bean $(50)$. Low dehydratreconstitution ability (34). For herbal tea, overall ac- ing temperatures $\left(40-60^{\circ} \mathrm{C}\right)$ have been highly recommendceptance is also an important quality criteria as it's greatly ed for the protection of thermal-bioactive substances in the affected to consumer demand (11). A remarkable change of dehydrated herbs (51). Dehydrating temperature over $60^{\circ} \mathrm{C}$ color has been clearly noticed on S. officinalis when air dry- induces a major damage to almost volatile constituents in ing temperature accelerated $50-55^{\circ} \mathrm{C}$ (38). A low air drying the dehydrated herbs (52). Moringa oleifera leaves should temperature around $30^{\circ} \mathrm{C}$ has not been encouraged owing be dehydrated by convective drying at $40^{\circ} \mathrm{C}$ to keep its pigto slow drying rate leading to low production capacity and ment (53). Accelerating the dehydrating temperature re-

Table 2. Effect of convective drying in different condition $\left({ }^{\circ} \mathrm{C} / \mathrm{hrs}\right)$ to antioxidant and organoleptic properties of steamed and dried S. procumbens.

\begin{tabular}{llllllc}
\hline Drying $\left({ }^{\circ} \mathrm{C} / \mathrm{hrs}\right)$ & Steamed & $\mathbf{3 5 / 8 . 0}$ & $\mathbf{4 0 / 7 . 5}$ & $\mathbf{4 5 / 7 . 0}$ & $\mathbf{5 0 / 6 . 5}$ & $\mathbf{5 5 / 6 . 0}$ \\
\hline $\begin{array}{l}\text { TPC } \\
(\mathrm{mg} \mathrm{GAE} / 100 \mathrm{~g})\end{array}$ & $141.12 \pm 0.23^{\mathrm{a}}$ & $111.54 \pm 0.07^{\mathrm{c}}$ & $128.13 \pm 0.05^{\mathrm{b}}$ & $132.41 \pm 0.06^{\mathrm{ab}}$ & $120.08 \pm 0.04^{\mathrm{bc}}$ & $93.15 \pm 0.05^{\mathrm{d}}$ \\
$\begin{array}{l}\text { TFC } \\
(\mathrm{mg} \mathrm{QE} / 100 \mathrm{~g})\end{array}$ & $79.42 \pm 0.06^{\mathrm{a}}$ & $51.04 \pm 0.03^{\mathrm{c}}$ & $65.23 \pm 0.04^{\mathrm{b}}$ & $71.24 \pm 0.02^{\mathrm{ab}}$ & $59.82 \pm 0.03^{\mathrm{bc}}$ & $30.74 \pm 0.02^{\mathrm{d}}$ \\
$\begin{array}{l}\text { DPPH } \\
\left(\mathrm{IC} \mathrm{C}_{50}, \mathrm{Mg} / \mathrm{ml}\right)\end{array}$ & $19.04 \pm 0.03^{\mathrm{d}}$ & $21.89 \pm 0.01^{\mathrm{b}}$ & $20.58 \pm 0.00^{\mathrm{c}}$ & $19.67 \pm 0.01^{\mathrm{cd}}$ & $21.05 \pm 0.00^{\mathrm{bc}}$ & $24.72 \pm 0.03^{\mathrm{a}}$ \\
$\begin{array}{l}\text { FRAP } \\
(\mathrm{mg} A A E / m l)\end{array}$ & $0.51 \pm 0.04^{\mathrm{a}}$ & $0.31 \pm 0.00^{\mathrm{c}}$ & $0.41 \pm 0.03^{\mathrm{b}}$ & $0.46 \pm 0.01^{\mathrm{ab}}$ & $0.36 \pm 0.02^{\mathrm{bc}}$ & $0.16 \pm 0.01^{\mathrm{d}}$ \\
$\begin{array}{l}\text { Overall acceptance } \\
\text { (score) }\end{array}$ & $7.07 \pm 0.02^{\mathrm{c}}$ & $7.31 \pm 0.02^{\mathrm{bc}}$ & $7.84 \pm 0.01^{\mathrm{ab}}$ & $8.12 \pm 0.03^{\mathrm{a}}$ & $7.57 \pm 0.02^{\mathrm{b}}$ & $6.11 \pm 0.00^{\mathrm{d}}$
\end{tabular}

more chance of fungi proliferation (39). Convective dehy- sults to lower antioxidant power in rosemary, meadowdration is used hot air as drying agent to exchange moisture sweet, motherwort, willow and peppermint $(54,55)$. Roselle between sample and hot air current in the drying cabinet. calyx dried at $35{ }^{\circ} \mathrm{C}$ under pressure -0.6 bar effectively preThe most advantages of convective dehydration can be serves the highest total phenolic and flavonoid content easily recognized as simple equipment, easy manipulation, (20). Polyscias fruticosa dried by convective drying at $45^{\circ} \mathrm{C}$ adequate expense and long stability. However, this drying for 6 hrs results to better retention of total phenolic, total method also reveals several backwards such as long drying flavonoid, DPPH radical-scavenging ability and FRAP ferric duration, oxidation of bioactive components, darkening reducing antioxidant power (36).

color, off flavor and rough surface on the dehydrated products (40). Convective drying creates finished samples with modified structural characteristics such as high hardening, high bulk density, more shrinkage, dense structure, low porosity. A great degradation of antioxidant activity, volatile removal and an accumulation of more yield of essential oil have been noticed on this dehydration method. Convective drying temperatures have been recommended at 50-70 ${ }^{\circ} \mathrm{C}$ to protect flavonoid and ascorbic acid in jujube (41); 65$73{ }^{\circ} \mathrm{C}$ to maintain flavonoids and phenolics in avocado (42); $50-70{ }^{\circ} \mathrm{C}$ for pomegranate (43), $50-60{ }^{\circ} \mathrm{C}$ for strawberry (44), $55-65{ }^{\circ} \mathrm{C}$ for cauliflower (45) to stabilize anthocyanin and ascorbic acid contents. In convective dehydration, the damage of antioxidant property derives from the raw material contact to oxygen. In an oxygen-limited space, degradation of phenolic substances and antioxidant attributes can be minimized by low temperature in convective drying (46). In order to preserve the highest total polyphenolic content, DPPH and FRAP, the convective drying temperatures have been recommended at $40{ }^{\circ} \mathrm{C}$ for date fiber $(47), 50-70{ }^{\circ} \mathrm{C}$ for

The effect of roasting at different conditions (140/30, $145 / 25,150 / 20,155 / 15$ and $160 / 10{ }^{\circ} \mathrm{C} / \mathrm{min}$ ) to antioxidant and organoleptic properties of dried and roasted Solanum procumbens has been definitely shown in Table 3 . It is rather easily found that roasting causes significant difference of antioxidant and organoleptic attributes of herbal tea. The dried Solanum procumbens contains a fair amount of total phenolic content $(132.41 \pm 0.06 \mathrm{mg} \mathrm{GAE} / 100 \mathrm{~g})$ and total flavonoid content $(71.24 \pm 0.02 \mathrm{mg} Q \mathrm{QE} / 100 \mathrm{~g})$ contributing to a proper antioxidant power with IC 50 of DPPH $(19.67 \pm 0.01$ $\mu \mathrm{g} / \mathrm{ml})$, FRAP $(0.46 \pm 0.01 \mathrm{mg} \mathrm{AAE} / \mathrm{ml})$ and overall acceptance $(8.12 \pm 0.03)$. The roasting at $150 / 20\left({ }^{\circ} \mathrm{C} / \mathrm{min}\right)$ causes a slight degradation of total phenolic content $(124.15 \pm 0.04 \mathrm{mg}$ $\mathrm{GAE} / 100 \mathrm{~g})$, total flavonoid content $(54.12 \pm 0.03 \mathrm{mg} \mathrm{QE} / 100$ $\mathrm{g}), \mathrm{IC}_{50}$ of DPPH $(20.14 \pm 0.02 \mu \mathrm{g} / \mathrm{ml})$, FRAP $(0.40 \pm 0.00 \mathrm{mg}$ $\mathrm{AAE} / \mathrm{ml})$; meanwhile overall acceptance has a great improvement $(8.96 \pm 0.01)$. Therefore roasting at $150 / 20\left({ }^{\circ} \mathrm{C} /\right.$ $\mathrm{min}$ ) can be applied for processing herbal tea from Solanum procumbens. Retention of bioactive components in 
Table 3. Effect of roasting in different condition $\left({ }^{\circ} \mathrm{C} / \mathrm{min}\right)$ to antioxidant and organoleptic properties of dried and roasted Solanum procumbens.

\begin{tabular}{|c|c|c|c|c|c|c|}
\hline Roasting $\left({ }^{\circ} \mathrm{C} / \mathrm{min}\right)$ & Dried & $140 / 30$ & $145 / 25$ & $150 / 20$ & $155 / 15$ & $160 / 10$ \\
\hline $\begin{array}{l}\text { TPC } \\
(\mathrm{mg} \text { GAE/100 g) }\end{array}$ & $132.41 \pm 0.06^{\mathrm{a}}$ & $100.13 \pm 0.04^{c}$ & $117.22 \pm 0.03^{b}$ & $124.15 \pm 0.04^{\mathrm{ab}}$ & $108.41 \pm 0.03^{\mathrm{bc}}$ & $73.18 \pm 0.02^{\mathrm{d}}$ \\
\hline $\begin{array}{l}\text { TFC } \\
\text { (mg QE/100 g) }\end{array}$ & $71.24 \pm 0.02^{\mathrm{a}}$ & $30.42 \pm 0.04^{c}$ & $48.38 \pm 0.01^{\mathrm{b}}$ & $54.12 \pm 0.03^{\mathrm{ab}}$ & $39.17 \pm 0.02^{\mathrm{bc}}$ & $18.47 \pm 0.01^{d}$ \\
\hline $\begin{array}{l}\text { DPPH } \\
\left(\mathrm{IC}_{50}, \mu \mathrm{g} / \mathrm{ml}\right)\end{array}$ & $19.67 \pm 0.01^{\mathrm{d}}$ & $22.58 \pm 0.00^{\mathrm{b}}$ & $20.91 \pm 0.03^{c}$ & $20.14 \pm 0.02^{c d}$ & $21.74 \pm 0.01^{b c}$ & $25.92 \pm 0.00^{\mathrm{a}}$ \\
\hline $\begin{array}{l}\text { FRAP } \\
(\mathrm{mg} \mathrm{AAE} / \mathrm{ml})\end{array}$ & $0.46 \pm 0.01^{\mathrm{a}}$ & $0.21 \pm 0.03^{c}$ & $0.32 \pm 0.01^{b}$ & $0.40 \pm 0.00^{\mathrm{ab}}$ & $0.27 \pm 0.03^{b c}$ & $0.09 \pm 0.02^{d}$ \\
\hline $\begin{array}{l}\text { Overall acceptance } \\
\text { (score) }\end{array}$ & $8.12 \pm 0.03^{c}$ & $7.29 \pm 0.00^{\mathrm{bc}}$ & $8.61 \pm 0.03^{\mathrm{ab}}$ & $8.96 \pm 0.01^{\mathrm{a}}$ & $8.42 \pm 0.00^{\mathrm{b}}$ & $7.05 \pm 0.03^{d}$ \\
\hline
\end{tabular}

Values are the mean of three replications; Mean values in row followed by the same letter/s are not differed significantly $(\alpha=\mathrm{P}=0.05$ )

Solanum procumbens will also contribute to humanity healthy benefit via daily consumption of this valuable herb. Three extents of roasting involve in the flavor, color and appearance of herbal tea, including roasting until brown, charred and carbonized (56). Time and temperature of roasting strictly correlate with moisture reduction and discoloration (57). Roasting induces a mild bitter taste and a slight green properties for herbal tea. This treatment eliminates a significant amount of tannin causing astringent feeling (58). Roasting barley at $280{ }^{\circ} \mathrm{C}$ in 20 s reduces $8 \%$ of phenolic content (25). DPPH of spearmint has been significantly decreased $60 \%$ after roasting (59). There is no significant difference of Ferric reducing antioxidant potential assay under roasting on black tea (60). Dried roselle calyx roasted at $135^{\circ} \mathrm{C}$ for $9 \mathrm{~min}$ effectively preserves the highest total phenolic and flavonoid content (20). Polyscias fruticosa roasted at $135 / 9\left({ }^{\circ} \mathrm{C} / \mathrm{min}\right)$ results to better retention of total phenolic, total flavonoid, DPPH radical-scavenging ability and FRAP ferric reducing antioxidant power (36). The most advantages of this research are the exploitation of the universal available equipments, there is no need to use hitech equipments to save investment capital. This is particularly benefit for small and medium house-hold scale production. However, limitations in utilization of steaming oven, convective drier, roasting oven in this research are quite long time, case hardening and slight decomposition of total phenolic content, total flavonoid content, DPPH, FRAP and minor degradation of overall acceptance.

\section{Conclusion}

Solanum procumbens Lour. contains numerous bioactive ingredients beneficial to human health. This research has successfully verified the impact of steaming, drying and roasting to antioxidant and organoleptic properties of steam-dry-roasted herbal tea from S. procumbens. The most total phenolic content, total flavonoid content, DPPH free radical scavenging, FRAP ferric reducing antioxidant and overall acceptance will be achieved by steaming at high temperature $\left(100^{\circ} \mathrm{C}\right)$ in short duration (45s), drying at intermediate temperature in a proper time $\left(45 / 7.0^{\circ} \mathrm{C} / \mathrm{hrs}\right)$, roasting at high temperature in short time $\left(150 / 20^{\circ} \mathrm{C} / \mathrm{min}\right)$. This research suggests that vapor steaming, convective drying and roasting can be utilized for processing functional herbal tea from medicinal S. procumbens in small and 8 . medium-scale production. This herbal tea can be a valuable source of functional components helpful for consumers in daily consumption.

\section{Acknowledgements}

Author acknowledge the financial support for the publication provided by Thu Dau Mot University, Binh Duong province, Vietnam.

\section{Compliance with ethical standards}

Conflict of interest: The author strongly confirms that this research is conducted with no conflict of interest.

Ethical issues: None.

\section{References}

1. Le HTA. Steroidal saponins from Solanum procumbens growing in Vietnam. Journal of Multidisciplinary Engineering Science and Technology 2017;4(9):8222-25. http://www.jmest.org/wpcontent/uploads/JMESTN42352403.pdf

2. Abhishek RU, Thippeswamy S, Manjunath K, Mohana DC. Antifungal and antimycotoxigenic potency of Solanum torvum Swartz. leaf extract: isolation and identification of compound active against mycotoxigenic strains of Aspergillus flavus and Fusarium verticillioides. Journal of Applied Microbiology. 2015;119(6):162436. https://doi.org/10.1111/jam.12956

3. Tran TTT, Dang HP, Nguyen TN. Chemical constituents from methanolic extract of Solanum procumbens Lour. (Solanaceae). Vietnam Journal of Science, Technology and Engineering. 2019;61(3):9-11.

4. Nguyen $\mathrm{XH}$, Nguyen TN, Nguyen TTM. Chemical constituents isolated from the whole plant of Solanum procumbens. Science and Technology Development Journal - Natural Sciences. 2019;2 (6):134-38. https://doi.org/10.32508/stdjns.v2i6.854

5. Nguyen NT, Tran TTT, Dang HP, Le HT, Nguyen XH, Do VNT, Nguyen TTM. A new 8,3'-neolignan from Solanum procumbens Lour., Natural Product Research. 2021;3:1-7. https:// doi.org/10.1080/14786419.2021.1916746

6. Deng LZ, Mujumdar AS, Zhang Q, Yang XH, Wang J, Zheng ZA, Gao ZJ, Xiao HW. Chemical and physical pretreatments of fruits and vegetables: Effects on drying characteristics and quality attributes - A comprehensive review. Critical Reviews in Food Science and Nutrition. 2019;59(9):1408-32. https:// doi.org/10.1080/10408398.2017.1409192

7. Sledz M, Wiktor A, Rybak K, Nowacka M, Witrowa-Rajchert D. The impact of ultrasound and steam blanching pre-treatments on the drying kinetics, energy consumption and selected properties of parsley leaves. Applied Acoustics. 2016;103:148-56. https:// doi.org/10.1016/j.apacoust.2015.05.006

8. Ahmed J, Shivhare US, Singh G. Drying characteristics and product quality of coriander leaves. Food and Bioproducts Processing. 2001;79(2):103-36. https:// doi.org/10.1205/096030801750286258 
9. Oboh G. Effect of blanching on the antioxidant properties of some tropical green leafy vegetables. Lwt - Food Science and Technology. 2005;38(5):513-17. https://doi.org/10.1016/ j.lwt.2004.07.007

10. Orphanides A, Goulas V, Gekas V. Drying technologies: Vehicle to high-quality herbs. Food Engineering Reviews. 2016;8(2):164-80. https://doi.org/10.1007/s12393-015-9128-9

11. Muller J. Convective drying of medicinal, aromatic and spice plants: a review. Stewart Postharvest Review. 2007;4:2.

12. Szychowski PJ, Lech K, Sendra E, Hernández F, Figiel A, Wojdyło A, Carbonell-Barrachina A. Kinetics, biocompounds, antioxidant activity and sensory attributes of quinces as affected by drying method. Food Chemistry. 2018;255:157-64. https:// doi.org/10.1016/j.foodchem.2018.02.075

13. Barbosa FDF, Barbosa LCA, Melo EC, Botelho FM, Santos RHS. Effect of drying air temperature upon the content and chemical composition of the essential oil from Lippia alba (Mill) N. E. Brown. Quimica Nova. 2006;29(6):1221-25.

14. Calin-Sanchez A, Lipan L, Cano-Lamadrid M, Kharaghani A, Masztalerz K, Carbonell-Barrachina AA, Figiel A. Comparison of traditional and novel drying techniques and its effect on quality of fruits, vegetables and aromatic herbs. Foods. 2020;9(9):1261. https://doi.org/10.3390/foods9091261

15. Pydi-Setty Y, Ramana-Murth JV. Development of a model for drying of solids in a continuous fluidized bed dryer. Indian Journal of Chemical Technology. 2003;10:477-82.

16. Ozbek B, Dadali G. Thin-layer drying characteristics and modelling of mint leaves undergoing microwave treatment. Journal of Food Engineering. 2007;83(4):541-49. https://doi.org/10.1016/ j.jfoodeng.2007.04.004

17. Fennell CW, Light ME, Sparg SG, Stafford GI, Van Staden J. Assessing African medicinal plants for efficacy and safety: Agricultural and storage practices. Journal of Ethnopharmacology. 2004;95(2-3):113-21. https://doi.org/10.1016/j.jep.2004.05.025

18. Mathlouthi M. Water content, water activity, water structure and the stability of foodstuffs. Food Control. 2001;12(7):409-17. https://doi.org/10.1016/S0956-7135(01)00032-9

19. Traore A, Diallo M, Gueye PEHO, Wague A, Lutgen P, Sarr O, Mboup S. Characterization of element and mineral content in Artemisia annua and Camellia sinensis leaves by handheld X-ray fluorescence. African Journal of Biotechnology. 2013;12(26):4179 -86. https://doi.org/10.5897/AJB12.2243

20. Minh PN. Various variables in production of dried Roselle (Hibiscus sabdariffa L.) calyx herbal tea. Bioscience Research. 2020;17(2):941-47. https://www.isisn.org/BR17(2)2020/941-94717(2)2020BR20-109.pdf

21. Tizian K, Jonathan IK, Vera G, Tabata RR, Steffen S, Dirk WL. A review of coffee by-products including leaf, flower, cherry, husk, silver skin, spent grounds as novel foods within the European Union. Foods. 2020;9:665. https://doi.org/10.3390/foods9050665

22. Borrelli RC, Esposito F, Napolitano A, Ritieni A, Fogliano V. Characterization of a new potential functional ingredient: Coffee silverskin. Journal Agriculture Food Chemistry. 2004;52(5):1338-43. https://doi.org/10.1021/jf034974x

23. Rungnattakan P, Preeyapa S, Suksan A, Patchanee Y, Aussama S. Effect of roasting and kneading on antioxidant activity and consumer acceptance towards asiatic pennywort tea. MATEC Web of Conferences 2018;187:01004.

https://doi.org/10.1051/ matecconf/201818701004

24. Marcason W. What is green coffee extract? Journal Acadamic Nutrient Dietary 2013;113(2):364. https://doi.org/10.1016/ j.jand.2012.12.004

25. Sharma P, Gujral HS. Effect of sand roasting and microwave cooking on antioxidant activity of barley. Food Research Interna- tional. 2011;44(1):235-40.

https://doi.org/10.1016/

j.foodres.2010.10.030

26. Josef M, Jason THK. Use of pressure manifestations following the water plasma expansion for phytomass disintegration. Water Science Technology. 2013;67(8):1695-700. https:// doi.org/10.2166/wst.2013.041

27. Josef M, Yoshikazu K, Masami U, Yoshinobu K. Commercial-scale utilization of greenhouse residues. Biotechnology and Applied Biochemistry. 2013;60(2):253-58. https://doi.org/10.1002/ bab.1055

28. Nguyen PM. Investigation of Thermal Treatment on Phytochemical Components of Artichoke (Cynara scolymus). Journal of Entomological Research. 2020;44(2):335-37. http:// dx.doi.org/10.5958/0974-4576.2020.00057.2

29. Singleton VL, Rossi JAJR. Colorimetry of total phenolics with phosphomolybdicphosphotungstic acid reagents. American Journal of Enology and Viticulture. 1965;16:144-58.

30. Mandal S, Patra A, Samanta A, Roy S, Mandal A, Mahapatra TD, Pradhan S, Das K, Nandi DK. Analysis of phytochemical profile of Terminalia arjuna bark extract with antioxidative and antimicrobial properties. Asian Pacific Journal of Tropical Biomedicine. 2013;3(12):960-66. https://doi.org/10.1016/S2221-1691(13)60186-0

31. Andriana Y, Xuan TD, Quy TN, Minh TN, Van TM, Viet TD. Antihyperuricemia, antioxidant and antibacterial activities of Tridax procumbens L. Foods. 2019;8:21. https://doi.org/10.3390/ foods 8010021

32. Benzie IFF, Strain JJ. The ferric reducing ability of plasma (FRAP) as a measure of antioxidant power: The FRAP assay. Analytical Biochemistry. 1996;239(1):70-76. https://doi.org/10.1006/ abio.1996.0292

33. Weil M, Sing ASC, Meot J, Boulanger R, Bohuon P. Impact of blanching, sweating and drying operations on pungency, aroma and color of Piper borbonense. Food Chemistry. 2017;219:274-81. https://doi.org/10.1016/j.foodchem.2016.09.144

34. Rodriguez O, Eim V, Rossello C, Femenia A, Carcel JA, Simal S. Application of power ultrasound on the convective drying of fruits and vegetables: Effects on quality. Journal of Science Food Agriculture. 2017;98(5):1660-73. https://doi.org/10.1002/jsfa.8673

35. Rocha T, Lebert A, Marty AC. Effect of pretreatments and drying conditions on drying rate and colour retention of basil (Ocimum basilicum). LWT. 1993;26(5):456-63.

36. Minh PN. Impact of roasting to total phenolic, flavonoid and antioxidant activities in root, bark and leaf of Polyscias fruticosa. Journal of Pharmaceutical Research International. 2020;32(2):13-17. https://doi.org/10.9734/jpri/2020/v32i230398

37. Muliterno MM, Rodrigues D, De Lima FS, Ida El, Kurozawa LE. Conversion/degradation of isoflavones and color alterations during the drying of okara. LWT. 2017;75:512-19. https://doi.org/10.1016/ j.lwt.2016.09.031

38. Venskutonis PR. Effect of drying on the volatile constituents of thyme (Thymus vulgaris L.) and sage (Salvia officinalis L.). Food Chemistry. 1997;59(2):219-27. https://doi.org/10.1016/S0308-8146 (96)00242-7

39. Hevia F, Melin P, Berti M, Fischer S, Pinochet C. Effect of drying temperature and air speed on cichoric acid and alkylamide content of Echinacea purpurea. Acta Horticulturae (ISHS). 2002;576:321-25. https://doi.org/10.17660/ActaHortic.2002.576.48

40. Raghavi L, Moses J, Anandharamakrishnan C. Refractance window drying of foods: A review. Journal of Food Engineering. 2018;222:267-75.

41. Wojdyło A, Figiel A, Legua P, Lech K, Carbonell-Barrachina A, Hernandez F. Chemical composition, antioxidant capacity, and sensory quality of dried jujube fruits as affected by cultivar and drying method. Food Chemistry. 2016;207:170-79. https:// 
doi.org/10.1016/j.foodchem.2016.03.099

42. Agudelo C, Barros L, Santos-Buelga C, Martinez-Navarrete N, Ferreira IC. Phytochemical content and antioxidant activity of grapefruit (Star ruby): A comparison between fresh freeze-dried fruits and different powder formulations. LWT 2017;80:106-12. https:// doi.org/10.1016/j.lwt.2017.02.006

43. Yılmaz FM, Yuksekkaya S, Vardin H, Karaaslan M. The effects of drying conditions on moisture transfer and quality of pomegranate fruit leather (pestil). Journal of Saudi Society Agriculture Science. 2017;16(1):33-40. https://doi.org/10.1016/ j.jssas.2015.01.003

44. Mendez-Lagunas LL, Rodriguez-Ramirez J, Cruz-Gracida M, Torres SS, Barriada-Bernal G. Convective drying kinetics of strawberry (Fragaria ananassa): Effects on antioxidant activity, anthocyanins and total phenolic content. Food Chemistry. 2017;230:174-81. https://doi.org/10.1016/j.foodchem.2017.03.010

45. Gupta M, Sehgal VK, Arora S. Optimization of drying process parameters for cauliflower drying. Journal of Food Science Technology. 2011;50:62-69. https://doi.org/10.1007/s13197-011-0231-5

46. Grant T, Ingegerd S, Federico GG. A review of drying methods for improving the quality of dried herbs, Critical Reviews in Food Science and Nutrition. 2021;61(11):1763-86. https:// doi.org/10.1080/10408398.2020.1765309

47. Borchani C, Besbes S, Masmoudi M, Blecker C, Paquot M, Attia H. Effect of drying methods on physico-chemical and antioxidant properties of date fibre concentrates. Food Chemistry. 2011;125 (4):1194-201. https://doi.org/10.1016/j.foodchem.2010.10.030

48. Calin-Sanchez A, Figiel A, Hernandez F, Melgarejo P, Lech K, Carbonell-Barrachina A. Chemical composition, antioxidant capacity and sensory quality of pomegranate (Punica granatum L.) arils and rind as affected by drying method. Food Bioprocess Technology. 2012;6:1644-54. https://doi.org/10.1007/s11947-012-0790-0

49. Michalska-Ciechanowska A, Wojdyło A, Lech K, Łysiak G, Figiel A. Effect of different drying techniques on physical properties, total polyphenols and antioxidant capacity of blackcurrant pomace powders. LWT 2017;78:114-21. https://doi.org/10.1016/ j.lwt.2016.12.008

50. Kyi TM, Daud WRW, Mohammad AB, Samsudin MW, Kadhum AAH, Talib MZM. The kinetics of polyphenol degradation during the drying of Malaysian cocoa beans. International Journal of Food Science Technology. 2005;40(3):323-31. https://doi.org/10.1111/ j.1365-2621.2005.00959.x
51. Shaw M, Meda V, Tabil L, Opoku A. Drying and color characteristics of coriander foliage using convective thin-layer and microwave drying. Journal of Microwave Power and Electromagnetic Energy. 2016;41(2):56-65. https://doi.org/10.1080/0832782311688559

52. Deans SG, Svoboda KP, Bartlett MC. Effect of microwave oven and warm-air drying on the microflora and volatile oil profile of culinary herbs. Journal of Essential Oil Research. 1991;3(5):341-47. https://doi.org/10.1080/10412905.1991.9697954

53. Ali MA, Yusof YA, Chin NL, Ibrahim MN, Basra SMA. Drying kinetics and colour analysis of Moringa oleifera leaves. Agriculture and Agricultural Science Procedia. $2^{\text {nd }}$ International Conference on Agricultural and Food Engineering (Cafe 2014) - New Trends Forward. 2014;2:394-400. https://doi.org/10.1016/ j.aaspro.2014.11.055

54. Harbourne N, Marete E, Jacquier JC, O'Riordan D. Effect of drying methods on the phenolic constituents of meadowsweet (Filipendula ulmaria) and willow (Salix alba). Lwt - Food Science and Technology. 2009;42(9):1468-73. https://doi.org/10.1016/ j.lwt.2009.05.005

55. Yi WG, Wetzstein HY. Effects of drying and extraction conditions on the biochemical activity of selected herbs. Horticulture Science. 2011;4(1):70-3. https://doi.org/10.21273/HORTSCI.46.1.70

56. Xu W, Shengpeng W, Junrong L, Yong J, Mingxing L, Jiliang C, Baolin B, Changjiang $\mathrm{H}$. Seeing the unseen of Chinese herbal medicine processing (Paozhi): Advances in new perspectives. Chinese Medicine. 2018;13:4. https://doi.org/10.1186/s13020-018-0163-3

57. Zzaman W, Yang TA. Moisture, color and texture changes in cocoa beans during superheated steam roasting. Journal of Food Processing and Preservation. 2014;38(3):1364-70. https:// doi.org/10.1111/jfpp.12098

58. Zhang J, Zhang ZZ, Zhou YB, Ling TJ, Wan. Chinese dark teas: Postfermentation, chemistry and biological activities. Food Research International. 2013;53(2):600-07. https://doi.org/10.1016/ j.foodres.2013.01.016

59. Lim YY, Murtijaya J. Antioxidant properties of Phyllanthus amarus extracts as affected by different drying methods. LWT-Food Science and Technology. 2007;40(9):1664-69. https:// doi.org/10.1016/j.lwt.2006.12.013

60. Naheed Z. Effect of rolling, fermentation and drying on the quality of black tea. Sarhad Journal of Agriculture. 2007;23:577-80 